\title{
Polycentricity and Collaborative Governance: Taiwanese Drug Prevention Policies and the Role of Policemen
}

\author{
Yan-Yi Chang ${ }^{1}$, Hsiang-Kai (Dennis) Dong ${ }^{2}$, Chung-Yuang Jan ${ }^{2}$, Rong-Yang Huang,"* \\ ${ }^{1}$ Department of Public Administration, Chung Hua University, Taiwan \\ ${ }^{2}$ Department of Public Administration, National Chengchi University, Taiwan \\ ${ }^{3}$ Department of Public Administration and Management, Chinese Culture University, Taiwan \\ *Corresponding Author: eryh25@gmail.com
}

Copyright $(02017$ by authors, all rights reserved. Authors agree that this article remains permanently open access under the terms of the Creative Commons Attribution License 4.0 International License

\begin{abstract}
A paradigm shift from a centralized authority system to a polycentric authority network has occurred in multiple areas of Drug Prevention due to the greater prevalence of collaborative governance. Drug policy is an example of a particularly contentious and polarized area in which governability is being critically examined. The Narcotics Hazard Prevention Act illustrates our government's strong tendency to enhance its governability. Sound governance of drug control usually involves a well design safety net and a wide range of capable actors and stakeholders that include policemen, public servants, practitioners, and other. Among these actors, the roles of policemen have been changed due to the fragmentation of authority and the reframing of the drug control structure. In this study, focus group and in-depth interviews will be applied to discuss the potential problems and issues, followed by two survey researches implemented for members of the Drug Abuse Prevention Center and Policemen of Precincts. From the perspective of Polycentricity and Collaborative Governance, the study found it plays more important role for the members of the Drug Abuse Prevention Center and Policemen of Precincts due to the inadequacy of the Narcotics Hazard Prevention Act.
\end{abstract}

Keywords Collaborative Governance, Drug Prevention, Policemen, Polycentricity, Stakeholders

\section{Introduction}

The drugs seized of Categories 3 and 4 have shown that a very large quantity of drugs of abuse in Taiwan. In terms of legal considerations, the Narcotics Hazard Prevention Act classifies narcotics as having four categories, i.e., Category 1 narcotics, Category 2 narcotics, Category 3 narcotics and Category 4 narcotics. ${ }^{1}$ The dependence strength of drug use are Category 1 more than Category 2, Category 2 more than Category 3, while Category 3 more than Category 4. Categories 3 and 4 seem unimportant, but it can also cause dependence. The primary goal of this paper is to explore the role conflicts and the source of fragmented authority caused by intergovernmental collaborations between different organizations, including the National Police Agency (Ministry of Interior), the Agency of Corrections (Ministry of Justice), and designated healthcare institutions (Ministry of Health and Welfare). This phenomenon is the result of overall change in vertical and horizontal governance.

The World Drug Report in 2013 noted that among Ketamines worldwide, $86.2 \%$ were cracked down on in Southeast Asia with Taiwan also included [31]. This news indicates how critical the situation of Category 3 and Category 4 narcotics in this region is. Categories 3 and 4 have seriously spread in Taiwan due to the problems with collaborative governance there from 2012 to 2014 regarding Category 3 and 4 as Table 1. Those Drugs of Category 3 and 4 are cheaper, easy to obtain, to attract a lot of drug addicts.

1 The term "Narcotics" in the Narcotics Hazard Prevention Act refers to those narcotic drugs and their derivative products that are habit-forming, cause abusive usage, and are a danger to society, as well as other substances and their products that affect psychological behavior. The narcotics are divided into four categories based on their extent of causing habitual usage, abusive usage, and danger to the society. The categories and their items are: 1. Category One: Heroin, Morphine, Opium, Cocaine, and their derivative products. 2. Category Two: Opium poppy, Coca, Cannabis, Amphetamines, Pethidine, Pentazocine, and their derivative products. 3. Category Three: Secobarbital, Amobarbital, Nalorphine, Ketamines, and their derivative products..4. Category Four: Allobarbital, Alprazolam, and their derivative products. 
Table 1. Drug Offenses

\begin{tabular}{|c|c|c|c|c|c|c|c|c|}
\hline \multirow[b]{2}{*}{ Year (Month) } & \multicolumn{2}{|c|}{ Against Narcotics Act } & \multicolumn{6}{|c|}{ Drugs Seized (Kilograms) } \\
\hline & $\begin{array}{c}\text { Offenses } \\
\text { (Cases) }\end{array}$ & $\begin{array}{l}\text { Offenders } \\
\text { (Persons) }\end{array}$ & Total & 1 st Category & 2nd Category & 3rd Category & 4th Category & Other \\
\hline 2012 & 44,001 & 47,043 & $2,960.90$ & 159.43 & 505.77 & $1,762.90$ & 532.69 & 0.11 \\
\hline 2013 & 40,130 & 43,268 & $4,412.52$ & 286.09 & $1,158.52$ & $2,028.77$ & 939.05 & 0.10 \\
\hline 2014 & 38,369 & 41,265 & $6,712.48$ & 123.53 & $1,096.15$ & $3,266.23$ & $2,226.16$ & 0.40 \\
\hline
\end{tabular}

Source: National Police Agency, Ministry of the Interior [27]

\subsection{Hands-on Experience Accumulated in Taiwan and Performance of Narcotics Preventive Strategies and the Collaterals}

\subsubsection{The hands-on Experiences Accumulated in Taiwan for Narcotics Preventive Strategies}

The evolution of narcotics issues in Taiwan resulted in the Drug-Elimination Program being launched in 1993 and the Central Anti-Drug Council officially established in 1994. The Narcotics Hazard Prevention Act was officially promulgated into enforcement in 1998. It is believed that the new act to have delivered a revolutionary reform where people addicted to narcotics were identified as having dual statuses, namely, both a "patient" and a "criminal." [32] And then the act had amended in 2003. In 2004, the President solemnly declared war on drugs and narcotics. The Ministry of Justice proposed its "New Anti-Drug Strategies" in December of 2004. The Executive Yuan officially declared the 2005-2008 period as the "Nationwide Anti-Drug War Years". In 2006, the Drug Abuse Prevention Centers were established extensively at city/county levels. Later, the Narcotics Hazard Prevention Act was partially amended in 2009 and 2010. Overall, since the partial amendment to the Narcotics Hazard Prevention Act was resolved in 2009, Ketamine addicts, the Category $3 \& 4$ narcotics, at the preliminary level increased at an astonishing pace. Under the amended Act, an addict who possesses such drugs within 20 grams with no intention or act to sell is not subject to criminal penalty and is only given a fine ranging from NT $\$ 10,000$ as the minimum to NT\$50,000 as the maximum and also required to attend an anti-narcotics compulsory lecture course for $4 \sim 8$ hours. As a natural result, the number of Category $3 \& 4$ addicts has become rampant. At the moment, addicts' sniffing Category 3 and 4 narcotics are not viewed as criminals and are primarily required to receive an administrative penalty and anti-drug compulsory lecture courses. Further, amidst the legislative evolvement process for the Narcotics Hazard Prevention Act, those addicted to drugs were classified as criminals, but later reclassified as patients instead, and treated with medication preferentially and any criminal penalty as only an auxiliary measure.

\subsubsection{Horizontal Network Links/Linkage and Central Government Governance}

In the Central Government, the Anti-Narcotics Council of Executive Yuan handles anti-narcotics tasks that involve inter-ministerial coordination mechanisms to make sure that narcotics issues are connected to issues found in internal affairs, medication, health, education, legal affairs and the like. These issues must face up to the challenges in the inter-ministerial policymaking process that are hardly observed in other policymaking processes handled by a single ministry. Next, both inter-ministerial coordination and communication should function as the key issues [11] [13]. In the terminal phase, issues of the implementation of policies rest with the authorities. Whereas the Department of Health implements drug-reduction policy, for instance, it becomes involved in the responsibilities and powers of varied authorities which then must coordinate themselves to form a close interrelationship. For case services, they must call for dedication with the resources already in society, including professional psychological consultants, social workers and case managers. Notwithstanding the significant amounts of anti-narcotics resources, the Central Government authorities simply failed to control the number of Category 3 and Category 4 narcotics addicts and keep that number from growing.

\subsubsection{Horizontal Network Links and Governance of Local Level Governments}

In terms of local level networks, in the conference convened by the Anti-narcotics Council of the Executive Yuan on June 2, 2006, the Premier instructed all Prosecutors' Offices under the Ministry of Justice to set up county (city) level Drug Abuse Prevention Centers. The Ministry of Justice in response immediately convened the Principal Public Prosecutors' Conference on June 5 of that year where the instructions of the Premier were then promulgated and underscored. The ranking executives requested that the principal public prosecutors of Prosecutors' Offices all over the country interview the local mayors and magistrates to urge positive efforts and the establishment of Drug Abuse Prevention Centers in twenty-five counties and cities. Subsequently thereafter, as six more municipalities came into being, they integrated the twenty-two municipal, county, city governments to set up Drug Abuse Prevention Centers and team up with the Ministry of Justice against narcotics and drugs in an attempt to achieve the maximum possible performance. In general, two major reasons led to the establishment of local level Drug Abuse Prevention Centers. The first is when the government authorities changed the anti-narcotics control and prevention policies to efforts that were designed to lower the origin of drug needs instead of continuing the previous emphasis which was an official 
crackdown on addicts. The second reason is when the government authorities wanted to set up horizontal connections between all anti-narcotics entities to produce an integrated government power instead of the previous practices where those entities operated in their own ways to minimize the hazards caused by narcotics.

In this study, we have begun by reviewing the concepts of stakeholders, polycentric governance, collaborative governance, and prevention of addiction and governance of narcotics. Then, it analyze the practices of poly-centricity and collaborative governance to drug prevention, for example, the narcotics, and compulsory measures, compulsory lecture courses, narcotics control and addiction prevention, and roles of the policemen. Also, we have discussed disputes or debates over collaborative governance of current policies to drug prevention. Finally, we have concluded the research at the end.

\section{Literature Review}

For research needs, the study proposes a theoretical framework that contains stakeholders, polycentric governance, collaborative governance, and prevention of addiction and governance of narcotics.

\subsection{Stakeholders}

Enforcement of a policy must always involve the stakeholder, e.g., the general public, policemen, people in charge of health, medical treatment personnel, education and laborers. Just in recent years of the anti-drug policy, the role of relevant policy stakeholder has been concerned with the governance. Amidst this process of governance, more and more "stakeholders" are brought together to participate in public affairs. Through this sort of links, diversified, comprehensive and multifaceted participants would join the interaction to produce the maximum possible consensus consistent with the need of the public and its citizens. The term "target population" denotes those people, organizations, or entities who change their behavior amidst the selection of proposals on public policies [3][14]. Target population in this paper as set forth here denote the interviewees from the central government, local governments, Drug Abuse Prevention Centers, policemen and Central Police University (focus group). For drug abuse management and control, there have a lot of stakeholders involved, and these stakeholders have some kind of relationship with each other.

\subsection{Polycentric Governance}

The term "polycentric governance" as set forth here denotes a case wherein each public governance units possess their own jurisdictional powers, and they only focus on their own business. All units are bestowed with their own respective functions. The polycentric governance mode, nevertheless, was characterized by efficiency as follows: (1)
The varied government units provide varied financial resource scales; (2) Among the varied governments, the relationship of cooperation exists; and (3) Other mechanisms are available to solve existing conflicts between the various units, e.g., the judicial authority. Polycentric governance exists simply for the purpose of providing varied services to a varied public to satisfy the favorites among various people. The ultimate goal for polycentric governance and is existence is efficiency in performance [23] [24]. In Europe, for example, anti-narcotics performance is built on multilevel governance [4] [10] [20]. Polycentric governance involves many institutions and public governance units. Polycentric governance is concerned about maintaining its own operations. Therefore, "efficiency" in the polycentric governance becomes more attention.

\subsection{Collaborative Governance}

In collaborative governance, Leach [19] noticed that public management operating in in concert would be characterized by seven key points, i.e., inclusiveness, representation, impartiality, transparency, deliberation, legality, and bestowed capability. Cooper, Bryer and Meek [7] expounded on the public management concert relationship as an aspect of citizenship and why citizens should participate and how. Koontzs and Thomas [17] analyzed environmental improvement management on the grounds of a concert relationship that would excel as a conventional managerial style. Further, McGuire [22] noticed that concert type public management would be a rationale for setting up public management and indeed mentioned the technique in terms of concert-grounded public management.

Collaborative governance primarily involves cooperation by and between the public and private sectors, mainly on public and private issues. The reason behind adopting such a united effort as a style is the desire to boost productivity, acquire information, obtain legality, and gain resources. The main reason behind such united efforts in narcotics is the desire to obtain information and maintain legality. More accurately speaking, the effort involves legality for the government in terms of ruling power, cross-sector issues [1], and collaborative governance between central and local governments [2] [6] [8] [26]. Collaborative governance is mainly based on cooperation, however, the level of cooperation will affect the implementation of the policy.

\subsection{Prevention of Addiction and Governance of Narcotics}

In Taiwan, there have been affluent studies' aiming at the issues found in Drug Abuse Prevention Centers, e.g., the issues of the set-up of mechanisms [15], transmission of public services [3] [21], linked relationship between networks of stakeholders[3] [33]. Thus, police authorities are not highly interested in rendering a hand, thus leaving quite some difficulty in drug abuser treatment [16]. There have 
been quite a few researchers trying to analyze the recommittal rates for new offenses by addicts after the Drug Abuse Prevention Center came into being[5] [29]. To go one more step further, the governance of narcotics should be based on evidence [18] [28] and stakeholders for politics so as to boost the capability of governance to manage narcotics issues. In the aspect of narcotics policy then, what is good governance [10] [30]. The governance of narcotics policy focuses at the Narcotics Abuse Act 1971 as well as British narcotics execution governance [25]. Disregarding the specific narcotics prevention and control measures, the policy processes can involve the play between the governance and its political roles [9] [12]. All narcotics management and control need evidence-based policy. The role of Drug Abuse Prevention Centers and policemen are very important for narcotics issues.

The theoretical connotation and concept that have discussed above will serve as the framework of this study. We have focused on the four dimensions: issues for narcotics, and compulsory measures, issues in compulsory lecture courses, integration of resources for narcotics control and addiction prevention, and pluralistic roles of the policemen.

\section{Research Design and Method}

\subsection{Research Design}

Narcotics prevention and control indeed suggest a network relationship, notably downward governance, horizontal governance, efforts to transmit that action through the first line of primary level public servants to the stakeholder. We conducted analyses on Category 3 and 4 narcotics toward, most notably, how to prevent and control the addiction and how to bring down the number of addicts. It has reviewed the relevant literature about the stakeholders, polycentric governance, collaborative governance, and prevention of addiction and governance of narcotics. Through examining the roles that stakeholders play in central and local level governments, we look into the enactment of narcotics prevention and policies for control.

\subsection{Research Method}

For the qualitative research effort, using a focus group, we invited 5 Professors from the Department of Crime Prevention and Corrections at Central Police University and 1 member of the Drug Abuse Prevention Center to meet on September 12, 2014.

We chose the interviewees primarily because they held the policymaking powers to examine the hands-on operation for prevention and the control policies for narcotics. There are 6 members at focus group. For more details, may see the list of Focus Group in Table 2.

Table 2. The members of focus group

\begin{tabular}{|c|c|c|}
\hline Code & Time & Objective \\
\hline FG1 & \multirow{6}{*}{$\begin{array}{l}\text { September } \\
12,2014\end{array}$} & $\begin{array}{l}\text { Professor, Department of Crime Prevention } \\
\text { and Corrections, Central Police University }\end{array}$ \\
\hline $\mathrm{FG} 2$ & & $\begin{array}{c}\text { Associate Professor, Department of Crime } \\
\text { Prevention and Corrections, Central Police } \\
\text { University }\end{array}$ \\
\hline FG3 & & $\begin{array}{l}\text { Assistant Professor, Department of Crime } \\
\text { Prevention and Corrections, Central Police } \\
\text { University }\end{array}$ \\
\hline FG4 & & $\begin{array}{l}\text { Professor, Department of Crime Prevention } \\
\text { and Corrections, Central Police University }\end{array}$ \\
\hline FG5 & & $\begin{array}{c}\text { Associate Professor, Department of Crime } \\
\text { Prevention and Corrections, Central Police } \\
\text { University }\end{array}$ \\
\hline FG6 & & $\begin{array}{l}\text { Section Chief, Drug Abuse Prevention } \\
\text { Center, Hsinchu County }\end{array}$ \\
\hline
\end{tabular}

We then adopted semi-structured in-depth interviews with stakeholders for a timeframe of May-June 2015. There are 3 members from central government and 5 members from local government. The interviewees are 8 members of central and local governments as table 3 .

Table 3. The list of interviewees

\begin{tabular}{|c|c|c|c|}
\hline Code & Levels & Time & Interviewee \\
\hline $\mathrm{C} 1$ & \multirow{3}{*}{$\begin{array}{l}\text { central } \\
\text { government }\end{array}$} & May 29, 2015 & Director, Department of Information, Ministry of Justice \\
\hline $\mathrm{C} 2$ & & June 1, 2015 & $\begin{array}{l}\text { Former Section Chief, National Police Agency (Chief, Liouquei } \\
\text { Precinct, Kaoshiung City Police Department) }\end{array}$ \\
\hline $\mathrm{C} 3$ & & June 16, 2015 & Secretary-general. Ministry of Health and Welfare \\
\hline L1 & \multirow{5}{*}{ local government } & May 15, 2015 & $\begin{array}{l}\text { Undertaker, Department of Social Affairs, Hsinchu City } \\
\text { Government }\end{array}$ \\
\hline L2 & & May 18, 2015 & Detective, Hsinchu City Police Bureau \\
\hline L3 & & May 18, 2015 & Detective, Hsinchu City Police Bureau \\
\hline L4 & & May 20, 2015 & Probation Officer, Hsinchu District Prosecutorial Office \\
\hline L5 & & May 22, 2015 & Case Manager, Drug Abuse Prevention Center, Hsinchu City \\
\hline
\end{tabular}


For the Quantitative research, we used purposive sampling to send questionnaires to members of Drug Abuse Prevention Centers and policemen of the Precinct. We aimed at Drug Abuse Prevention Centers for a total of twenty-two municipality, county (city) governments for the timeframe of June 2015. There were 69 members at the Drug Abuse Prevention Centers to fill the questionnaire. For policemen at the Precinct, there were 43 policemen who could fill up the questionnaires. We chose the policemen and members of the Drug Abuse Prevention Centers as the targets of the research, as they take charge of the key roles in compulsory lecture course lessons, referrals and crackdowns on addicts in the Drug Abuse Prevention Centers. Questionnaires are shown in Table 4.

Table 4. Questionnaires of Drug Abuse Prevention Centers and Precinct

\begin{tabular}{|c|c|c|c|}
\hline \multicolumn{2}{|c|}{ Drug Abuse Prevention Centers } & \multicolumn{2}{|c|}{ Precinct } \\
\hline Time & $\begin{array}{c}\text { Number of } \\
\text { questionnaires }\end{array}$ & Time & $\begin{array}{c}\text { Number of } \\
\text { questionnaires }\end{array}$ \\
\hline June 2015 & 69 & June 2015 & 43 \\
\hline
\end{tabular}

\section{The Relationship of Poly-centricity to Collaborative Governance}

\subsection{Issues for Narcotics, and Compulsory Measures}

\subsubsection{Should Category 3 narcotics, Ketamine, be upgraded} to be Category 2 narcotics?

Among the members of the focus group, examining the status quo and the origin of narcotics, Associate Professor of the Department of Crime Prevention and Corrections at the Central Police University spoke up on his views:

In terms of newly emerging addicts, the numbers addicted with Amphetamine and Ketamine (it belongs to Category 3 ) have grown at a rapid pace as well. The issues related Ketamine deserve serious watchfulness. Narcotics sniffers tend to transfer, and traffickers always try hard to find new alternates routes (or alternative drug combinations). The effect of the new alternates cannot easily be controlled and naturally incur intangible costs. The efforts in the compulsory training programs also prove to be little or no avail. (Code FG2).

The very reasons for Category 3 and 4 are that the imposed penalty is perfunctory, not compulsory. Ironically, the venues even become the very sere addicts exchange updates. For repeated offenders (recidivists), the compulsory lecture courses should be changed into penalties that deprive liberty, or Ketamine should be upgraded to a Category 2 narcotic to deliver rehabilitation treatment that can be more effective (code FG4).

From the members of the focus group, where compulsory training programs are sponsored in formal groups simply for show, we can hardly expect substantial results. One compulsory training program is sponsored for as many as 200 or even 300 addicts, of whom, as many as $70 \%$ doze off during the sessions. The compulsory training sites ironically function as venues when addicts can exchange information and data. The Category $3 \& 4$ narcotics contain too many items, e.g., the fairy water/raping liquid, MDMA and the like which have been confused by abusers, significantly complicating the problems and making these narcotics hard to identify.

Besides, the problems found in Category 3 and Category 2, drug prevention also faces considerable difficulties. As one interviewee said,

The current business of drug prevention encounters a number of bottlenecks, including the lack of manpower, and money. The drug population is now almost mainstream crime (Code J).

They are largely inclined toward Category 3 narcotics, so Ketamine should not be upgraded to Category 2 primarily because there have been too many newly emerging Category 3 and 4 narcotics, which could hardly be put under the most effective control. To the contrary, some scholars and experts hold that Ketamine should be upgraded from Category 3 to Category 2 narcotics. In summation, should Ketamine and those Category 3 narcotics be upgraded immediate into a law enforcement category as Category 2 narcotics? No distinct conclusion has been reached to date by the focus group members.

\subsubsection{For Category 3 and 4 Narcotics Addicts, there have been no Compulsory Measures.}

There have also not been any compulsory measures or effective countermeasures for narcotics. The members of the focus group held the following views:

Toward Category $3 \& 4$ narcotics addicts, even repeated offenders, there have been merely [an] administrative penalty and compulsory lecture courses. There have not been any effective countermeasures against the cases where they are absent. As a natural result, the number of offenders have been moving upward continually without any policy of deterrence. It is suggested that the laws and ordinances concerned should be updated with reference to the procedures and mechanism against sexual assaults or domestic violence. (Code FG3).

County/city governments face the same problem, as the Drug Abuse Prevention Center for Case Tracking doesn't have the coercive power. Thus the relevant policies, laws and regulations need to be amended (Code FG1).

Scholars hold that comprehensive coordinating measures are even more important. Regarding the aforementioned hands-on practices and theories of scholars and experts, other 
than the compulsory lecture courses imposed in accordance with the Criteria for Unified Penalty and Regulations Governing Compulsory Lecture Courses on Narcotics Hazard Events, all the municipal, county (city) governments are facing similar or even the same problems. A Drug Abuse Prevention Center lacks binding enforcement over addict cases. The governments must invest more manpower and resources. For the three and four narcotics addicts, one interviewee said,

For those repeat offenders that are three \& four narcotics addicts, the effect of lecture courses is very limited (code L3).

For a relevant class lecture design among different authorities, one interviewee said,

Each authority has its own tasks as assigned by the Ministry of Justice (Code L2).

As we have seen from the above description, there are no coercive forces of the Category $3 \& 4$ narcotics addicts. The main reasons from the provisions of the Narcotics Hazard Prevention Act are simply not strict.

\subsection{Issues Found in Compulsory Lecture Courses}

As to the Criteria for Unified Penalty and Regulations Governing Compulsory Lecture Courses on Narcotics Hazard Events that are currently prevalent, the members of focus group from the Central Police University offered their point of view:

Regarding Ketamine, he holds that a Ketamine addict should not be classified as a criminal. For most people, nevertheless, an administrative penalty is believed lacking in functions, either in compulsory lecture courses or any imposition of default penalty, with the function being below $30 \%$ (Code FG5).

In a compulsory lecture course, the guardians should assume a significant responsibility. The parents of addicts should be required to join the addicts in the compulsory lecture courses. Where the family function is not performed, the social resources should get involved. Besides, the contents of the compulsory lecture courses should focus on pluralistic multivariate interests to touch the addicts, playing micro movies, for instance (Code FG3).

Other than the addicts themselves who should participate in compulsory lecture courses, their family members are required to render support. At the moment, the compulsory lecture courses yield ineffective results and cannot provide eradication treatment. The Criteria for Unified Penalty and Regulations Governing Compulsory Lecture Courses on Narcotics Hazard Events oriented compulsory lecture courses should not remain merely compulsory lecture courses, with only an administrative penalty that lacks a deterrence function. For repeated offenders, coordinating measures appear to be quite important.

\subsection{Integration of Resources for Narcotics Control and Addiction Prevention}

In terms of narcotics addicts, it is not the case that there are no authorities rendering support or treatment. Instead, the addicts must shuttle between quite a many different authorities to report their presence. It is not a lack of resources but rather double resources instead. Those resources should be integrated and staffed systematically with corresponding support based on the varied situations and their demands. The members of the focus group of the Drug Abuse Prevention Center of Hsinchu County pointed out:

In the integration of resources in the non-government sector, the very important key point is: We should make sophisticated use of religious powers which are extremely mighty and far-reaching as extremely powerful momentum in support of narcotics control and prevention. In this regard, we should cultivate more useful human resources, which should be covered by the utilization of resources to expand the range of narcotics control and prevention (Code FG6).

Integration of resources in terms of non-government aspects can prevent double waste and uneven distribution of resources. We should set up the list of resources available in the jurisdictional regions to render resources and services without a need to go too far (Code FG3).

In terms of the viewpoints of the Drug Abuse Prevention Center and Hsinchu County as the hands-on enforcer, if we place Category 3 and 4 narcotics into control in the future, the Drug Abuse Prevention Centers indeed can call for a more binding force to manage and support those cases. ${ }^{2}$ In other words, the law enforcement against narcotics (eradication) should be a task that is assigned downwardly. They perform their duties just under the level of professional ethics. From the perspective of narcotics control and prevention, as one interviewee said,

Executive ineffective enforcement authority does not mean there is a problem; however, the level of concern of the county (city) government will be the key point (Code L5).

From the above description, local governments play the

2 In terms of community treatment, we should reference the methodology of practices in other businesses to render varied community treatments for different cases. Amidst limited prison capacity, there must be other methods to use for community treatment, and rehabilitation treatment which should be amended in a flexible manner, so that the Drug Abuse Prevention Centers in counties and cities would get the authority for law enforcement, implementation of links, and treatment with resources. 
key role in the implementation of narcotics enforcement, for the reason that local governments need more resources to integrate narcotics control and prevention for addicts.

\subsection{Pluralistic Roles of the Policemen}

Amidst the complicated attributes involved in administrative affairs, whenever a task calls for compulsory enforcement, the administrative authorities tend to pass the task on to the policemen. Under the legal system that is currently prevalent, all administrative authorities are supposed to exercise compulsory enforcement in principle at least. Yet in the long run, whenever a task calls for compulsory enforcement, the administrative authorities nevertheless tend to pass that task on to the policemen for enforcement. As a natural result, the support given by the policemen authorities to the administrative authorities in compulsory enforcement becomes a regular job. (Hung, Chang, Shiu, and Chen, 2015). In addition to the policemen mission, there is a role for policemen in the Drug Abuse Prevention Center, as one interviewee explained,

The police are one of the members of the Drug Abuse Prevention Center, and its design is based on the identity of the main police enforcement. In addition to the policemen, other members of the Drug Abuse Prevention Center should have public authority (Code c1).

We did interview a former department head of the National Police Agency, Ministry of the Interior, and the incumbent sub-administrative Director of Municipality. He pointed to the role played by the policemen:

For Category 3 and 4 narcotics, the National Police Agency, Ministry of the Interior is not subject to command and dispatch from the Ministry of Justice. Policemen are still under the command of the National Police Agency, Ministry of the Interior. In terms of the relationship by and between both parties, the Ministry of Justice and the National Police Agency, and even the Minister of the Interior is not empowered to command policemen unless the superior renders a hand. Regarding the viewpoints on narcotics, there is still room with and between the National Police Agency, Ministry of the Interior and the Ministry of Justice for further coordination and communication. (Code c2).

For Category 3 and 4 narcotics, under the laws and regulations currently prevalent, a sniffer with a possession within the limit of 20 grams was only subject to administrative penalty and compulsory lecture courses far from being enough penalties for any successful deterrence. The legislative authorities by enacting laws would only make policemen extremely busy and discourage policemen morale. The relationship by and between both parties of the National Police Agency, Ministry of the Interior, and Ministry of
Justice is not in either a sound or close cooperation. The policemen support for the local level Drug Abuse Prevention Centers is still under the command of the National Police Agency, Ministry of the Interior or the county (city) level policemen bureaus. In addition to same drug policy, there were indeed different aspects, as one interviewee said,

For the drug prevention business, they will get involved in cooperation at the inter-bureau. It has produced a hydra-headed bureaucracy (Code L1).

The question is whether the central government and the local government can tame the hydra-headed bureaucracy and make it function more smoothly for drug prevention. As one interviewee said,

For the business of the policemen, they should unify and integrate their own practices to aid the performance of the Ministry of Justice, the National Police Agency, and Local Government. (Code L4)

The Ministry of Health and Welfare is responsible for mental health, and the Ministry of Justice is responsible for policy formulation. I remembered on meeting, for Category 3 and 4 narcotics legislation provisions, discussing how to set a standard of narcotics. Then, the representative from the Ministry of Justice said 20 grams was the upper limit for Category 3 and 4 narcotics (Code c3).

The goals of Ministry of Health and Welfare and Ministry of Justice are totally different. The main reasons come from the division of government agencies and professionalism.

Accordingly, we explained the narcotics, and compulsory measures, compulsory lecture courses, narcotics control and addiction prevention, and roles of the policemen. These four perspectives are directly related to the Categories 3 and 4 narcotics due to the Narcotics Hazard Prevention Act is not complete. However, the attitude of the Drug Abuse Prevention Center and Precinct Policemen are very significant.

\subsection{Drug Abuse Prevention Center and Precinct Questionnaires}

In addition to the four perspectives that have indicated in the theoretical framework, we have also mentioned the perspectives of Prevention of Addiction and Governance of Narcotics. In this section, we have conducted the questionnaires to the Drug Abuse Prevention Center and Precinct as below.

\subsubsection{Drug Abuse Prevention Center}

Of all the respondents in the Drug Abuse Prevention Center, more than half (62.3\%) thought that the Drug Abuse Prevention Center has a good relationship with the Police Bureau and Education Bureau; only 18.8\% disagreed with this statement. Also about $46.4 \%$ of the respondents thought 
that the governability of the Drug Abuse Prevention Center had effectively reduced the number of addicts. In addition, more than half $(58 \%)$ of the respondents indicated that they clearly know their mission, which is to communicate vertically with the central and local governments and horizontally with other ministries.

As far as strengthening both policy implementation and networking, the vast majority $(91.3 \%)$ thought that establishing a dominant status for the Drug Abuse Prevention Center would be one of the most useful approaches. There were also $63.7 \%$ of the respondents who thought that the Drug Abuse Prevention Center should be given more authority, such as for conducting the urine screening test. However, although the government has invested a great deal of resources into preventing and controlling narcotics usage, the number of narcotics addicts has still increased in the past few years. Among many of the reasons that could have caused such a phenomenon, more than half $(53.6 \%)$ of the respondents in the Drug Abuse Prevention Center thought that Article 11-1 of the Narcotics Hazard Prevention Act is the primary reason, followed by poor implementation of policies $(49.2 \%)$ and inadequate and inefficient coordination among government agencies $(46.4 \%)$.

However, when it comes to moving official drug authority from the Ministry of Justice to the Ministry of Health and Welfare, only $36.2 \%$ of the respondents supported this idea. Similarly, only $37.6 \%$ of the respondents agreed with the statement that said that policemen always actively cooperate with the Drug Abuse Prevention Centers. The majority either disagreed with this statement or held a neutral opinion. The questionnaire distribution is shown in Table 5.

Table 5. Descriptive statistics of Drug Abuse Prevention Center Members

\begin{tabular}{|c|c|c|c|c|c|c|}
\hline$\#$ & Content of issues & Appropri & $\begin{array}{l}\text { S (The fis } \\
\text { High - }\end{array}$ & vithin par & $\begin{array}{l}\text { es repres } \\
\rightarrow \text { Low }\end{array}$ & number) \\
\hline 1 & $\begin{array}{c}\text { Drug Abuse Prevention Center has a good } \\
\text { relationship with Policemen Bureau, Education } \\
\text { Bureau and etc. }\end{array}$ & $\begin{array}{l}29.0 \% \\
(20)\end{array}$ & $\begin{array}{c}33.3 \% \\
(23)\end{array}$ & $\begin{array}{c}18.8 \% \\
(13)\end{array}$ & $\begin{array}{l}11.6 \% \\
(8)\end{array}$ & $\begin{array}{l}7.2 \% \\
(5)\end{array}$ \\
\hline 2 & $\begin{array}{l}\text { Amidst the process of concerted governance for } \\
\text { narcotics prevention, policemen authorities could } \\
\text { effectively bring down the addicts who are sniffing. }\end{array}$ & $\begin{array}{l}11.6 \% \\
(8)\end{array}$ & $\begin{array}{c}34.8 \% \\
(24)\end{array}$ & $\begin{array}{l}31.9 \% \\
(22)\end{array}$ & $\begin{array}{c}14.5 \% \\
(10)\end{array}$ & $\begin{array}{l}7.2 \% \\
(5)\end{array}$ \\
\hline 3 & $\begin{array}{l}\text { Do you know the role played by the Ministry of } \\
\text { Justice in the Drug Abuse Prevention Centers? }\end{array}$ & $\begin{array}{c}17.4 \% \\
(12)\end{array}$ & $\begin{array}{c}40.6 \% \\
(28)\end{array}$ & $\begin{array}{c}29.0 \% \\
(20)\end{array}$ & $\begin{array}{l}7.2 \% \\
(5)\end{array}$ & $\begin{array}{c}5.8 \% \\
(4)\end{array}$ \\
\hline 4 & $\begin{array}{l}\text { Narcotics sniffing problems primarily result from } \\
\text { drug addiction, so it is proposed that overall charge } \\
\text { jobs should be converted to the Ministry of Health } \\
\text { and Welfare instead of the current } \\
\text { Ministry of Justice. }\end{array}$ & $\begin{array}{l}11.6 \% \\
(8)\end{array}$ & $\begin{array}{c}24.6 \% \\
(17)\end{array}$ & $\begin{array}{l}31.9 \% \\
(22)\end{array}$ & $\begin{array}{c}14.5 \% \\
(10)\end{array}$ & $\begin{array}{c}17.4 \% \\
(12)\end{array}$ \\
\hline 5 & $\begin{array}{l}\text { Establish the positioning of the Drug Abuse } \\
\text { Prevention Center, and the establishment of dedicated } \\
\text { units and personnel to strengthen the implementation } \\
\text { of policies and the cooperation between networks }\end{array}$ & $\begin{array}{l}52.2 \% \\
(36)\end{array}$ & $\begin{array}{c}39.1 \% \\
(27)\end{array}$ & $\begin{array}{l}2.9 \% \\
(2)\end{array}$ & $\begin{array}{l}2.9 \% \\
(2)\end{array}$ & $\begin{array}{l}2.9 \% \\
(2)\end{array}$ \\
\hline 6 & $\begin{array}{c}\text { Give law enforcement the authority of the Drug } \\
\text { Abuse Prevention Center, such as } \\
\text { a urine screening test }\end{array}$ & $\begin{array}{l}33.3 \% \\
(23)\end{array}$ & $\begin{array}{l}30.4 \% \\
(21)\end{array}$ & $\begin{array}{l}14.5 \% \\
(10)\end{array}$ & $\begin{array}{l}10.1 \% \\
(7)\end{array}$ & $\begin{array}{l}11.6 \% \\
(8)\end{array}$ \\
\hline 7 & $\begin{array}{l}\text { The policemen always take the initiative to support } \\
\text { the Narcotics Prevention Centers in tasks of the Drug } \\
\text { Abuse Prevention Centers. }\end{array}$ & $\begin{array}{c}13.0 \% \\
(9)\end{array}$ & $\begin{array}{c}24.6 \% \\
(17)\end{array}$ & $\begin{array}{c}36.2 \% \\
(25)\end{array}$ & $\begin{array}{c}17.4 \% \\
(12)\end{array}$ & $\begin{array}{l}8.7 \% \\
(6)\end{array}$ \\
\hline 8 & $\begin{array}{l}\text { Notwithstanding the heavy amounts of resources } \\
\text { invested by the government in preventing and } \\
\text { controlling narcotics, the number of narcotics addicts } \\
\text { rises year-by-year. The preliminary reason is the } \\
\text { negative effect of legal issues in the "Narcotics } \\
\text { Hazard Prevention Act", Article 11-1. }\end{array}$ & $\begin{array}{c}24.6 \% \\
(17)\end{array}$ & $\begin{array}{c}29.0 \% \\
(20)\end{array}$ & $\begin{array}{l}34.8 \% \\
(24)\end{array}$ & $\begin{array}{l}5.8 \% \\
(4)\end{array}$ & $\begin{array}{l}5.8 \% \\
(4)\end{array}$ \\
\hline 9 & $\begin{array}{l}\text { Notwithstanding the heavy amounts of resources } \\
\text { invested by the government to prevent and control } \\
\text { narcotics, the number of narcotics addicts rises } \\
\text { year-by-year. The preliminary reason is the } \\
\text { inadequate united efforts in concert. }\end{array}$ & $\begin{array}{c}20.3 \% \\
(14)\end{array}$ & $\begin{array}{l}26.1 \% \\
(18)\end{array}$ & $\begin{array}{c}24.6 \% \\
(17)\end{array}$ & $\begin{array}{c}21.7 \% \\
(15)\end{array}$ & $\begin{array}{c}7.2 \% \\
(5)\end{array}$ \\
\hline 10 & $\begin{array}{l}\text { Notwithstanding the heavy amounts of resources } \\
\text { invested by the government toward preventing and } \\
\text { controlling narcotics, the number of narcotics addicts } \\
\text { rises year-by-year. The preliminary reason is poor } \\
\text { enforcement of government policies. }\end{array}$ & $\begin{array}{l}21.7 \% \\
(15)\end{array}$ & $\begin{array}{c}27.5 \% \\
(19)\end{array}$ & $\begin{array}{c}31.9 \% \\
(22)\end{array}$ & $\begin{array}{c}13.0 \% \\
(9)\end{array}$ & $\begin{array}{c}5.8 \% \\
(4)\end{array}$ \\
\hline
\end{tabular}




\subsubsection{Precinct Policemen}

Among all the respondents in the Policy Precinct, 44.2\% knew the Drug Abuse Prevention Centers have been established. However, only $34.9 \%$ of the respondents knew that the mission of the Drug Abuse Prevention Center is to communicate vertically with the central and local governments and horizontally with other ministries. However, when it comes to the issue of switching the official drug authority from the Ministry of Justice to the Ministry of Health and Welfare, $58.1 \%$ of the respondents supported this idea. Compared with the percentage found in the previous table, this number increased by more than $20 \%$ and is thus significantly larger.

Different from the findings of the Drug Abuse Prevention Center, only $33.6 \%$ of the policemen thought that they can effectively reduce the number of addicts. Also, even though only $62.4 \%$ of the respondents in the Drug Abuse Prevention Center thought that the policemen did not actively cooperate with them, $48.8 \%$ of the policemen thought that they did. More than $81.4 \%$ of the policemen agreed that arresting narcotics usage is one important source of performance scores. However, more than half $(55.9 \%)$ of the policemen thought that arresting narcotics users should be separated from calculating performance scores. Otherwise, policemen may not have enough incentives to arrest category Three or Four narcotics users since the scores they could get are relatively fewer.

Again, although the government invested a great deal of resources on preventing and controlling narcotics usage, the number of narcotics addicts kept increasing. Among many of the reasons that caused such a phenomenon, more than three-fourths (76.7\%) of the policemen thought that Article 11-1 of the Narcotics Hazard Prevention Act was the primary reason. This view is consistent with the findings from the Drug Abuse Prevention Center. The second and third reasons suggested by the policemen were inadequate and inefficient coordination among government agencies $(62.8 \%)$ and poor implementation of policies $(53.5 \%)$. That distribution is seen in Table 6.

Table 6. Descriptive statistics of Policemen of Precincts

\begin{tabular}{|c|c|c|c|c|c|c|}
\hline \# & Contents of issues & \multicolumn{5}{|c|}{$\begin{array}{c}\text { Appropriateness (The figures within parentheses represent the number) } \\
\text { High } \stackrel{\text { Low }}{\longrightarrow}\end{array}$} \\
\hline 1 & $\begin{array}{l}\text { Do you know Drug Abuse Prevention Centers have been } \\
\text { established? }\end{array}$ & $\begin{array}{c}23.3 \% \\
(10)\end{array}$ & $\begin{array}{c}20.9 \% \\
(9)\end{array}$ & $\begin{array}{c}27.9 \% \\
(12)\end{array}$ & $\begin{array}{c}7.0 \% \\
(3)\end{array}$ & $\begin{array}{c}20.9 \% \\
(9)\end{array}$ \\
\hline 2 & $\begin{array}{l}\text { Do you know about the role played by the Ministry of } \\
\text { Justice at the Drug Abuse Prevention Centers? }\end{array}$ & $\begin{array}{c}11.6 \% \\
(5)\end{array}$ & $\begin{array}{c}23.3 \% \\
(10)\end{array}$ & $\begin{array}{c}34.9 \% \\
(15)\end{array}$ & $\begin{array}{c}9.3 \% \\
(4)\end{array}$ & $\begin{array}{c}20.9 \% \\
(9)\end{array}$ \\
\hline 3 & $\begin{array}{l}\text { Where narcotics sniffing problems primarily result from } \\
\text { drug addiction, it is proposed that the overall charge of } \\
\text { jobs should be given to the Ministry of Health and } \\
\text { Welfare instead of the current Ministry of Justice. }\end{array}$ & $\begin{array}{c}30.2 \% \\
(13)\end{array}$ & $\begin{array}{c}27.9 \% \\
(12)\end{array}$ & $\begin{array}{l}20.9 \% \\
(9)\end{array}$ & $\begin{array}{l}7.0 \% \\
(3)\end{array}$ & $\begin{array}{l}14.0 \% \\
(6)\end{array}$ \\
\hline 4 & $\begin{array}{l}\text { Amidst the process for concerted governance of narcotics } \\
\text { prevention, policemen and the authorities could } \\
\text { effectively bring down sniffing addicts. }\end{array}$ & $\begin{array}{l}7.0 \% \\
(3)\end{array}$ & $\begin{array}{c}25.6 \% \\
(11)\end{array}$ & $\begin{array}{c}25.6 \% \\
(11)\end{array}$ & $\begin{array}{l}16.3 \% \\
(7)\end{array}$ & $\begin{array}{c}25.6 \% \\
(11)\end{array}$ \\
\hline 5 & $\begin{array}{l}\text { In terms of their importance in t Drug Abuse Prevention } \\
\text { Centers, the policemen always take the initiative to } \\
\text { support the tasks of the Narcotics Prevention Centers. }\end{array}$ & $\begin{array}{l}20.9 \% \\
(9)\end{array}$ & $\begin{array}{c}27.9 \% \\
(12)\end{array}$ & $\begin{array}{c}32.6 \% \\
(14)\end{array}$ & $\begin{array}{l}4.7 \% \\
(2)\end{array}$ & $\begin{array}{l}14.0 \% \\
(6)\end{array}$ \\
\hline 6 & $\begin{array}{c}\text { The crackdown on narcotics is consistently linked with } \\
\text { performance scores. }\end{array}$ & $\begin{array}{c}51.2 \% \\
(22)\end{array}$ & $\begin{array}{c}30.2 \% \\
(13)\end{array}$ & $\begin{array}{c}11.6 \% \\
(5)\end{array}$ & $\begin{array}{c}4.7 \% \\
(2)\end{array}$ & $\begin{array}{c}2.3 \% \\
(1)\end{array}$ \\
\hline 7 & $\begin{array}{l}\text { The crackdown on narcotics should be separated from } \\
\text { performance scores. For instance, for Category } 3 \text { and } 4 \\
\text { narcotics, if the policemen receive low performance } \\
\text { scores, they become less interested in cracking down on } \\
\text { such addicts. }\end{array}$ & $\begin{array}{l}23.3 \% \\
(10)\end{array}$ & $\begin{array}{c}32.6 \% \\
(14)\end{array}$ & $\begin{array}{l}11.6 \% \\
(5)\end{array}$ & $\begin{array}{l}16.3 \% \\
(7)\end{array}$ & $\begin{array}{l}16.3 \% \\
(7)\end{array}$ \\
\hline 8 & $\begin{array}{l}\text { Notwithstanding the heavy amount of resources invested } \\
\text { by the government to prevent and control narcotics, the } \\
\text { number of narcotics addicts still increases year-by-year. } \\
\text { The preliminary reason is the negative effect of the } \\
\text { "Narcotics Hazard Prevention Act", Article 11-1 on legal } \\
\text { issues }\end{array}$ & $\begin{array}{c}48.8 \% \\
(21)\end{array}$ & $\begin{array}{c}27.9 \% \\
(12)\end{array}$ & $\begin{array}{l}11.6 \% \\
(5)\end{array}$ & $\begin{array}{l}7.0 \% \\
(3)\end{array}$ & $\begin{array}{l}4.7 \% \\
(2)\end{array}$ \\
\hline 9 & $\begin{array}{l}\text { Notwithstanding the heavy amount of resources invested } \\
\text { by the government in preventing and controlling } \\
\text { narcotics, the number of narcotics addicts rises } \\
\text { year-by-year. The preliminary reason is inadequate united } \\
\text { efforts done in concert. }\end{array}$ & $\begin{array}{l}41.9 \% \\
(18)\end{array}$ & $\begin{array}{l}20.9 \% \\
(9)\end{array}$ & $\begin{array}{l}18.6 \% \\
(8)\end{array}$ & $\begin{array}{l}9.3 \% \\
(4)\end{array}$ & $\begin{array}{l}9.3 \% \\
(4)\end{array}$ \\
\hline 10 & $\begin{array}{l}\text { Notwithstanding the heavy amount of resources invested } \\
\text { by the government in preventing and controlling } \\
\text { narcotics, the number of narcotics addicts rises } \\
\text { year-by-year. The preliminary reason is poor enforcement } \\
\text { of government policies. }\end{array}$ & $\begin{array}{l}32.6 \% \\
(14)\end{array}$ & $\begin{array}{l}20.9 \% \\
(9)\end{array}$ & $\begin{array}{l}14.0 \% \\
(6)\end{array}$ & $\begin{array}{l}11.6 \% \\
(5)\end{array}$ & $\begin{array}{l}20.9 \% \\
(9)\end{array}$ \\
\hline
\end{tabular}


Based on the descriptive statistics above, it could be found that the members of Drug Abuse Prevention Centers and Policemen of Precincts are very close of mutual cooperation. This can be seen as collaborative governance.

\section{Discussion and Analysis: The Dispute over Collaborative Governance}

According to the objectives of the focus group and the in-depth interviews, and data collection from the questionnaires, the results of this ae study are discussed further below.

\subsection{Downward Governance and Network- Oriented Governance: A Horizontal and Vertical Relationship}

The Ministry of Justice operates downwardly compared to municipality, county (city) level Drug Abuse Prevention Centers that operate upwardly. The Central Government has set up a horizontal network governance, e.g., Ministry of Education, Ministry of National Defense, Ministry of Health and Welfare and the like. The municipality, county (city) governments have set up horizontal network governance, e.g., Division of Education, Bureau of Health, and the Police Administrations. With such close and rightly working networks, there are still lots of loopholes. The main key personnel in these networks are policemen and members of Drug Abuse Prevention Centers. The former assumes the responsibility for crackdown, while the latter assumes the responsibility for tracing and enforcement. Legal enforcement and management simply work hand-in-hand.

\subsection{Too many coordinating authorities: In Same Boat, but not for Teamwork}

First, regarding narcotics control and prevention, the authorities at the Central Government level include the Ministry of Justice, Ministry of Health and Welfare, National Police Agency, Ministry of the Interior, Ministry of Education, Ministry of National Defense, and the like. In terms of narcotics, the Ministry of Justice holds viewpoints of its own. Any crackdown on narcotics primarily calls for efforts by policemen. Psychological rehabilitation is the job of the Ministry of Health and Welfare. All three jobs are attributed to the same and are in the same situation, i.e., services for only narcotics addicts, but have different orientations regarding the hydra-headed problem, and are in a tug of war between professionalism and inter-ministerial coordination. What the Ministry of Health and Welfare keeps in mind is rehabilitation for addicts, while what the National Police Agency, Ministry of the Interior, is concerned about is enforcement of the crackdown on addicts; What the Ministry of Justice is concerned about is drug addict- related laws, with laws resting at the very front of the policy, enforcement in the middle, and rehabilitation as the last part.

\subsection{The Headache in Enforcement of Anti-Drug Network Policies: Gaps in the Link between Local Governance and Inter-Department Narcotics Control and Prevention}

The Central Government and the local level governments have set up an anti-drug network governance link. Meanwhile, through the focus group, we analyzed the narcotics control and prevention network integration where we noticed the problems that have already emerged. All authorities simply go their own ways. Local level Drug Abuse Prevention Centers are now bestowed with mandatory powers and thus could not substantially put into implementation thorough tracing and support. The very momentum to assure such substantial tracing still rests with the policemen. Meanwhile, if we want to prevent a waste or uneven distribution of resources due to doubling of resources, the local municipality, county (city) level Drug Abuse Prevention Centers should prudently set up a list of resources within their jurisdiction so as to render effective resources and services to the subject cases. In this regard, nevertheless, we are facing another difficulty because the list of resources within their jurisdiction involves teamwork by and among the policemen and the health and education authorities.

\subsection{The Legislative Authorities: Breakdown in Governance and Issues related to Legal Enactment}

Relatively, varied points of view were heard and where they hold concerns the bad timing for upgrading Ketamine from Category 3 and 2 narcotics. Even if Ketamine is upgraded from in category, there will be newly emerging narcotics that will replace Ketamine. In short, the effort to upgrade Ketamine from Category 3 narcotics to Category 2 narcotics is still not the right "cure" to solve the problem in a timely way. In terms of Criteria for Unified Penalty and Regulations Governing Compulsory Lecture Courses on Narcotics Hazard Events for oriented compulsory lecture courses, those in the focus group mentioned that the current administrative compulsory lecture courses are virtually ineffective. The relevant focus group touched on this same issue, proposing that a significantly harsher way to monitor compulsory lecture courses should be adopted. These relevant analytical discussions concluded that the current practices with only an administrative penalty and compulsory lecture courses for Category 3 and 4 narcotics cannot effectively deter continued addiction.

\subsection{Conflicts with Role of the Policemen}

The policemen should listen to more pluralistic multivariate authorities. Other than the crackdown on unlawful narcotics ordered by the National Police Agency, Ministry of the Interior, the policemen should also team up with the Ministry of Justice and participate with the municipality, county (city) governments and the Hazard Control \& Prevention Task Forces in Drug Abuse Prevention 
Centers to crack down on narcotics, blood sampling of addicts, and tracing urine tests of former rehabilitation treatment cases, The policeman should also team up with the communities in terms of interviewing drug eradication cases. In short, the policemen must take better charge of the complicated tasks related to crackdown, blood taking, tracing, and interviews. Moreover, there are issues concerning the link between crackdown management and performance. Most importantly, the National Police Agency, Ministry of the Interior is bestowed with the power to command and dispatch policemen. The Ministry of Justice, nevertheless, lacks the power for dispatch and can only coordinate with the National Police Agency, Ministry of the Interior. Moreover, policemen are assigned to handle hundreds of tasks where different municipality, county (city) governments might have different requirements for policemen. The breakdown in law enforcement leads to the breakdown in management and eventually the breakdown in policemen performance amidst the excessively heavy duties placed on their shoulders.

\section{Conclusions}

Indeed, the key issues related to narcotics involve not merely laws, but medical treatment and management as well. The issue of drug problem management is not a single one in terms of attributes. It involves management of issues in different governments, i.e., administrative management. In such pluralistic governance, there are varied ways to treatment due to the different environments. In turn, the narcotics control and prevention policies appear to involved intense narcotics network control and prevention and a horizontal and vertical network relationship. Even amidst such a right and close network relationship, the narcotics sniffer population significantly still increases. The very reason behind that increase is the fact that narcotics are easily available and the authorities over narcotics who have been in charge of everything ironically, nothing after all are producing hydra-headed headache that lacks sound channels for effective coordination.

This study used qualitative research to study focus group objectives and in-depth interviewees which showed that those authorities that are in charge are virtually "on one team but not of one mind". We analyzed the Focus group's dialogue features and in-depth interviewees delivered personal their thoughts which complemented the deficiency found in the questionnaires. In Taiwan, the very radical problems involved narcotics have too lenient a penalty for Category $3 \& 4$ narcotics addiction, and addicts could find ways to bypass any penalty using the loopholes, i.e., being arrested at this moment and released in another moment, and vice versa, leaving no incentives for the policemen authorities to crack down on addicts. The Ministry of Justice, on the other hand, disagrees about imposing any criminal penalty on narcotics addicts to prevent the overcrowded jails, leading to double headaches in governance and even a breakdown in governance performance. Amidst these solid legal grounds, the authorities fail to come produce effective management. Looking at Taiwan's narcotics prevention and control, members of the Drug Abuse Prevention Centers and Policemen of Precincts will be more difficult to face the narcotics issues due to the imperfect Narcotics Hazard Prevention Act. As a result, the polycentricity and collaborative governance of drug policy will be more fragmented.

\section{REFERENCES}

[1] Adler, Paul S. 1995. Interdepartmental interdependence and coordination: the case of the design/manufacturing interface. Organization Science 6(2): 147-167.

[2] Agranoff, Robert. 2006. Inside collaborative networks: ten lessons for public managers. Public Administration Review 66(special issue): $56-65$.

[3] Chang, Yan-yi, Chun-yuan Wang and Cheng-feng Wu. 2011. Policy design, network governance of public sector and the transfer of the social construction of target population: the analysis of drug control policy. Competitiveness Review 14: 73-100(in Chinese)

[4] Chatwin, Caroline. 2007. Multi-level governance: the way forward for European illicit drug policy? International Journal of Drug Policy 18(6): 494-502.

[5] Chen, Chuan-His, Yan-Pin Chi, and Chung-Yuang Jan. 2011. Evaluation of recidivism in addicts who received methadone maintenance treatment in Taiwan for 18 months. Taiwan Journal of Public Health 31(5): 485-497.(in Chinese)

[6] Christensen, Tom, and Per Lægreid, 2008. The challenge of coordination in central government organizations: the Norwegian case. Public Organization Review 8: 97-116.

[7] Cooper, Terry L., Thomas A. Bryer, and Jack W. Meek. 2006. Citizen-centered collaborative public management. Public Administration Review 66(special issue): 76-88.

[8] Donahue, John D. and Richard J. Zeckhauser. 2012. Collaborative Governance: Private Roles for Public Goals in Turbulent Times. Princeton: Princeton University Press.

[9] Duke, Karen and Betsy Thom.2014. The role of evidence and the expert in contemporary processes of governance: the case of opioid substitution treatment policy in England. International Journal of Drug Policy 25(5): 964-971.

[10] Edwards, Carel and Maurice Galla. 2014. Governance in EU illicit drugs policy. International Journal of Drug Policy 25(5): 942-947.

[11] Graber, Doris A. 2003. The Power of Communication: Managing Information in Public Organizations. Washington, D.C.: Congressional Quarterly.

[12] Houborg, Esben and Vibeke Asmussen Frank. 2014. Drug consumption rooms and the role of politics and governance in policy processes. International Journal of Drug Policy 25(5): 972-977. 
[13] Hung, Wen-Ling, Charles Kuang-Ming Chang, Yih-Bao Shiu, and Huei-Yuan Chen. 2015. The Study of Cross-Organization Mechanism and Its Legal System. Taipei: National Development Council. (In Chinese)

[14] Ingram, H. and A. Schneider.1991. The Choice of Target Populations. Administration and Society, 23(3): 333-56.

[15] Jan, Chung-Yuang, and Yan-Yi Chang. 2007. The mechanism design of drug abuse control center in Taiwan: the comparative analysis of global governance system. Yan Kao Shuang Yue Kan, 262: 84-94. (In Chinese)

[16] Jan, Chung-Yuang and Chuan-His Chen. 2011. The primary factors that affect the efficacy of drug prevention policies in Taiwan. Taiwan Journal of Public Health, 30:6: 604-616(in Chinese)

[17] Koontzs, Tomas M, and Craig Thomas. 2006. What do we know and need to know about the environmental outcomes of collaborative management. Public Administration Review 66(special issue): 111-121

[18] Lancaster, Kari. 2014. Social construction and the evidence-based drug policy endeavor. International Journal of Drug Policy 25(5): 948-951.

[19] Leach, William D. 2006. Collaborative public management and democracy: evidence from western watershed partnerships. Public Administration Review 66(special issue): $100-110$

[20] Lin, Shoei-Po and Chang-Yen Li. 2005. Governance across Boundaries. Taipei: Wunan. (In Chinese)

[21] Lipsky, Michael. 2010. Street-level Bureaucracy: Dilemmas of the Individual in Public Services. Expanded edition. New York: Russell Sage Foundation.

[22] McGuire, Michael. 2006. Collaborative public management: assessing what we know and how we know It. Public Administration Review 66 (special issue): 33-43.

[23] McGinnis, Michael D. ed. 1999a. Poly-centricity and Local Public Economics: Readings from the Workshop in Political Theory and Policy Analysis. Ann Arbor, Michigan: The University of Michigan Press.
[24] McGinnis, Michael D. ed. 1999b. Polycentric Governance and Development. Ann Arbor, Michigan: The University of Michigan Press.

[25] Monaghan, Mark. 2014. Drug policy governance in the UK: lessons from changes to and debates concerning the classification of cannabis under the 1971 Misuse of Drugs Act. International Journal of Drug Policy 25(5): 1025-1030.

[26] Moseley, Alice, and Oliver James. 2008. Central state steering of local collaboration: assessing the impact of tools of meta-governance in homelessness services in England. Public Organization Review 8: 117-136.

[27] National Police Agency, Ministry of the Interior. Available online: http://www.npa.gov.tw/NPAGip/wSite/mp?mp=4

[28] Roberts, M. 2004. Comment on what are drug users looking for when the contact drug services abstinence or harm Reduction?" Drugs Education Prevention and Policy 12: 261263.

[29] See, Lai-Chu, Hui-Tzu Tu, Yi-Hua Huang, Heng-Jung Lien, Hui-Chun Huang, Hae-Lang Wei, and Sheue-Rong Lin. 2012. Recidivism rates of released drug offenders after the local drug abuse prevention center implemented in Taiwan. Show Chwan Medical Journal 11(3-4): 75-87. (in Chinese)

[30] Singleton N. and J Rubin. 2014. What is good governance in the context of drug policy? International Journal of Drug Policy 25(5): 935-941.

[31] Wälti, Sonja, and Daniel Kübler. 2003. 'New governance' and association pluralism: the case of drug policy in Swiss cities. Policy Studies Journal 31(4): 499-525.

[32] United Nations Office on Drugs and Crime. 2013. World Drug Report. New York: United Nations.

[33] Yen, Liang Kung and Jung-Hong Lin. 2011. The policy implementation of local drug abuse control center--a policy network perspective. Soochow Journal of Political Science 29:2: 111-180(in Chinese) 